\title{
UDC 541.128.3:549.67:547.262 \\ CONVERSION OF METHANOL TO HYDROCARBONS ON BIMETALLIC CATALYSTS ON THE BASIS OF ZSM-5
}

\author{
T.A.Babaeva \\ Baku State University \\ azeri09@mail.ru \\ Received 18.04.2019 \\ Accepted 22.11.2019
}

\begin{abstract}
The conversion of methanol to hydrocarbons over ZSM-5 zeolite modified with transition metals $-\mathrm{Zn}, \mathrm{Zr}$ and $\mathrm{La}-$ is described. The interdependence of reaction parameters - temperature, contact time, and catalyst acidity - in controlling $\mathrm{C}_{2}-\mathrm{C}_{3}$ olefins selectivity are is characterized and interpreted. It is found that binary modification of ZSM-5 increased the selectivity of target products. Some of the unique properties of La$\mathrm{Zr} / \mathrm{HZSM}-5$ catalyst are apparently due to the combination of strongly acidic and weak acid sites.
\end{abstract}

Keywords: zeolite, ZSM-5, HZSM, Zn, Zr, La, methanol, MTO, MTP, methanol-to-hydrocarbons.

doi

\section{Introduction}

The production of $\mathrm{C}_{2}-\mathrm{C}_{4}$ olefins is a largescale and constantly growing stream due to their wide range applications in the chemical and oil refining. Usually low-molecular olefins are obtained from the pyrolysis processes of liquefied petroleum gas, gasoline fractions, and catalytic cracking of vacuum distillates. However, the limited oil and gas reserves and the expected decline in oil production [1] require searching for other available hydrocarbon sources. Natural gas (NG) and methanol are the raw material types, which recently have been offered for producing lower molecular olefin as promising [1-3].

Mobil oil and UOP Norsk/Hydro have developed $[4,5]$ the conversion of methanol to gasoline (MTG) and olefins in the presence of mesoporous materials SAPO-34 (silicoaluminophosphate) and ZSM-5. The traditional industrial methods for producing olefins are the superior in efficiency due to lower temperature and higher selectivity for the desired products ethylene and propylene. However, achieving a high yield of propylene in this process remains a challenge.

Molecular sieves based on SAPO-34 modified with transition metals ( $\mathrm{Co}, \mathrm{Mn}$ and $\mathrm{Ni}$ ) were studied in the reaction of methanol to olefins (MTO) $[2,6,7]$. The total activity of these catalysts for production of $\mathrm{C}_{2}-\mathrm{C}_{4}$ olefins was comparable to the activity of unmodified SAPO34 , but there was a significant difference with respect to deactivation. In the case of Ni-SAPO34 , extraordinarily high amount of methane was found in the products [7]. It was found that MnSAPO-34 is the best catalyst for both lowmolecular olefins and the deactivation stage [8].

The high catalytic thermal stability and resistance to coke formation properties of ZSM5 makes it very promising catalyst for the MTO reaction among used mesoporous materials [9].

The modifying effects of $\mathrm{Cs}, \mathrm{Ca}, \mathrm{Sr}, \mathrm{Fe}$, and Ce metals on the activity and selectivity of HZSM-5 zeolite in conversion of methanol to light olefins and aromatic hydrocarbons were studied $[10,11]$. It has been established that the presence of metals in catalysts increased selectivity regarded light olefins in all cases. High propylene selectivity was observed for HZSM-5 modified with Cs due to the changes in the location of acidic sites.

The authors of [12] for the HZSM-5 catalyst observed the high selectivity for propylene $(42.2 \%)$ with a high silicon content modified by alkaline treatment.

The selectivity of the catalyst related to $\mathrm{C}_{2}-\mathrm{C}_{3}$ olefins substantially depends on the size and structure of the pores of the zeolite crystal lattice [13, 14]. The catalyst acidity is another factor affecting the selectivity of the catalyst. It is necessary for reducing the concentration of Lewis centers to increase the selectivity and stability of the catalyst, and this rule is true for all studied types of molecular sieves [15].

It was found that the catalytic properties of MFI structured zeolites strongly depend on combinations of transition metals and acid sites 
for the process of methanol to olefins [16]. Contradictory to HZSM-5 (H-AlMFI), zeolite HFeAlMFI showed higher selectivity for propylene, and zeolite H-GaAlMFI higher selectivity for aromatic hydrocarbons. The bimetallic $\mathrm{H}-$ FeGaAlMFI catalyst demonstrated the highest activity in the MTO process.

Regarding olefin selectivity the catalysts may be placed in the following: HZSM-5 $<$ CrZSM-5<V-ZSM-5<Mn-ZSM-5<Ni-ZSM-5<ZrZSM-5 = Ti-ZSM-5< Fe-ZSM-5 $<$ Co-ZSM-5 [2, $17,18]$.

Although, several researches showed how product distribution changed during the reaction over ZSM-5, but an increase in olefin selectivity is usually accompanied by a decrease in the stability of the catalyst. In addition, full details including the dependence of acidic sites and reaction yields have not been reported.

We guess that the inclusion of transition metals in the composition of zeolite catalysts leads to the strict ordering available acid centers and appearance of new active centers that can directly interact with hydrocarbons to form intermediates in the process of methanol conversion and impart the multifunctional character to a catalyst.

Thus, in this research, effect of using different transition metals such as zinc $(\mathrm{Zn})$, lanthanum (La), zirconium ( $\mathrm{Zr}$ ) and their combinations ( $\mathrm{Zr}-\mathrm{Zn}, \mathrm{La}-\mathrm{Zr}, \mathrm{Zn}-\mathrm{La})$ as well as the nature and concentration of transition metals on the acidity on conversion of methanol $\mathrm{C}_{2}-\mathrm{C}_{3}$ olefin hydrocarbons was investigated.

\section{Experimental part}

ZSM-5 type of zeolite with a molar ratio of $\mathrm{Si} / \mathrm{Al}=58$ was used for experiments. The catalyst was converted by ion exchange into the $\mathrm{NH}_{4}$ form according to the procedure [9]. The $\mathrm{H}$-form of the zeolite was obtained by thermal decomposition of the $\mathrm{NH}_{4}$-form at $500^{\circ} \mathrm{C}$ for 4 hours. Catalysts modified with 1.0 mass.\% metals were obtained by impregnation of the $\mathrm{H}$-form zeolite with nitrates of $\mathrm{La}$ and $\mathrm{Zn}$, and oxychloride of zirconium $\left(\mathrm{ZrOCl}_{2} \cdot 8 \mathrm{H}_{2} \mathrm{O}\right)$. The catalysts samples were afterward dried for 16 hours, then for 4 hours in a drying oven at $110^{\circ} \mathrm{C}$ and calcined for 4 hours in a muffle furnace at $550^{\circ} \mathrm{C}$. The experiments were carried out on a flow-type setup with a fixed bed layer of a catalyst at atmospheric pressure in the temperature range $300-400^{\circ} \mathrm{C}$. The volume of the catalysts used for the experiments in the plug flow reactor was $4 \mathrm{~cm}^{3}$ and volumetric feed rate was $2 \mathrm{~h}^{-1}$. The duration of the experiment was $1.0 \mathrm{~h}$. The initial reactant used was methanol with a purity of 99.8\% (provided by Merck). The acidic properties of zeolites were studied by the thermal desorption of ammonia [9], and reaction products were identified by gas chromatography (Agilent GC 7820A).

\section{Results and discussion}

Methanol in the presence of H-ZSM-5 is converted into a mixture of $\mathrm{C}_{1}-\mathrm{C}_{12}$ hydrocarbons at the temperature range $300-400^{\circ} \mathrm{C}$. Although, ZSM-5 sample shows high activity, but it is quickly deactivated due to coke formation (Figure 1).

It practically loses activity in the formation of hydrocarbons by $30 \mathrm{~min}$ of the reaction time. Moreover, the conversion of methanol to hydrocarbons is reduced from 39.1 to $10.8 \%$, the yield of gaseous and liquid hydrocarbons decreases and simultaneously the yield of dimethyl ether increases because of zeolite deactivation.

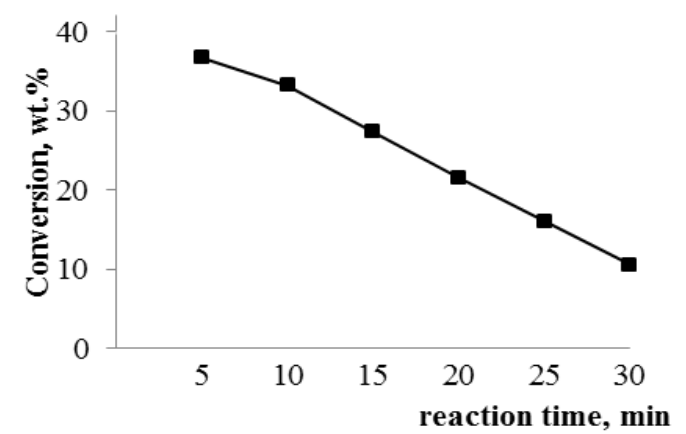

Fig. 1. Catalytic activity of ZSM-5 catalyst in the conversion of methanol to hydrocarbons.

We have applied various Me-ZSM-5 catalysts for the methanol conversion. The effect of the nature of transition metals on the yield of low molecules olefin hydrocarbons in the methanol conversion reaction is shown on Figure 2. 


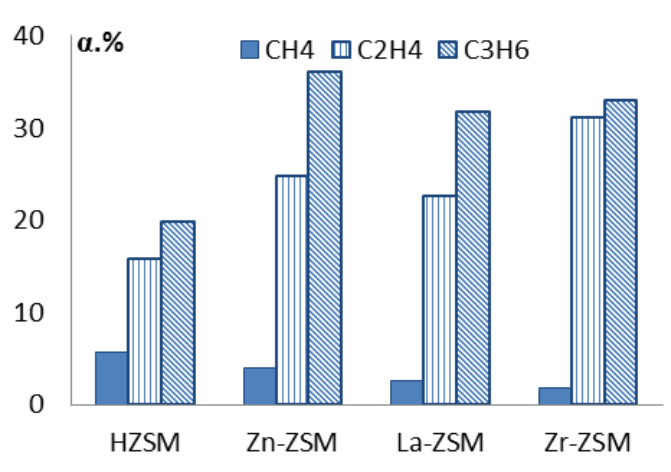

Fig. 2. The influence of the nature of the metal on the yield of methane, ethylene and propylene, mass.\%

It is seen that in the case of modification ZSM-5 with zinc leads to decrease in the content of methane and alkane $\mathrm{C}_{2}-\mathrm{C}_{5}$ to $16.8 \%$. In the case of zeolite modified by lanthanum, the methane content also decreases and the alkane content increases. Moreover, the modification of ZSM-5 with zinc and lanthanum significantly increases the yield of ethylene (15.8 to $24.8 \%$ ) and propylene (19.9 to $36.2 \%$ ). Zirconium modified catalyst (Zr-ZSM-5) showed high selectivity where a high content of ethylene $(31.2 \%)$ and propylene $(33.1 \%)$ as well as the least amount of methane and alkanes is formed.

Thus, it is established that among the above samples, zeolite catalysts modified with zinc, lanthanum and zirconium shows the highest selectivity for lower olefins, including ethylene and propylene. It should be noted that high amount of propylene obtain on lanthanum and zinccontaining catalysts, and much more ethylene is on $\mathrm{Zr}$-modified one catalyst (Table 1).

The data the Table 1 explains the effect on the selectivity of a zeolite catalyst for ethylene or propylene of binary combination of modifying elements. Propylene selectivity increases on bimetallic catalysts, while the least number of alkanes is obtained on the La$\mathrm{Zr} / \mathrm{HZSM}-5$ bimetallic catalyst.

It has been found that the stability of the ZSM-5 depends on reaction temperature and contact time. As it is seen from Figure 3 the formation of $\mathrm{C}_{2}-\mathrm{C}_{3}$ olefins, especially ethylene, is favored to lower temperatures where conversion of methanol to hydrocarbons is only $4.0-6.0 \%$.

The observed behavioral change in the selectivity of ethylene and propylene formation probably occurs due to the acidic properties change of HZSM-5 zeolite because of chemical modification. As can be seen from Table 2, the selectivity of propylene will be involved with the least number of alkanes that formed on La$\mathrm{Zr} / \mathrm{ZSM}-5$ in all cases.

Apparently, the presence of strong Bronsted acid sites on the outer and inner surfaces of the zeolite (Table 2) caused intensive dimerization, oligomerization of ethylene with the subsequent cyclization and the formation of aliphatic and aromatic hydrocarbons.

Table 1. The effect of the nature of the metal introduced into the composition of zeolite ZSM-5 on its catalytic properties in the conversion of methanol $\left(\mathrm{T}=400^{0} \mathrm{C}, \mathrm{V}=2.0 \mathrm{~h}^{-1}\right)$

\begin{tabular}{|l|c|c|c|c|c|c|}
\hline \multirow{2}{*}{ Catalysts } & $\begin{array}{c}\text { Methanol conver- } \\
\text { sion, \% }\end{array}$ & \multicolumn{5}{|c|}{ Reaction yields, \% } \\
\cline { 3 - 7 } & & $\sum \mathrm{C}_{2}-\mathrm{C}_{5}$ & ethylene & propylene & Methane & alkane $\mathrm{C}_{1}-\mathrm{C}_{5}$ \\
\hline Zn-LaZSM-5 & 39.1 & 69.9 & 25.1 & 32.8 & 3.5 & 26.5 \\
\hline Zn-ZrZSM-5 & 38.8 & 82.6 & 28.4 & 41.8 & 2.1 & 15.1 \\
\hline La-ZrZSM-5 & 38.5 & 88.5 & 28.8 & 47.9 & 2.7 & 8.7 \\
\hline
\end{tabular}

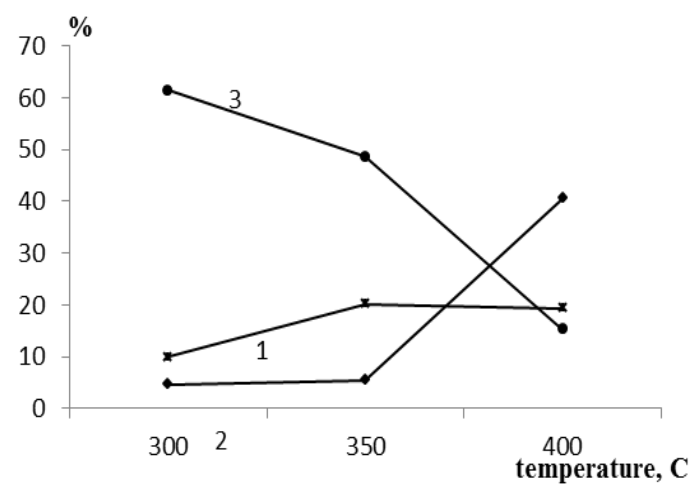

Fig. 3. The effect of temperature to ZSM-5 catalyst activity in the methanol conversion reaction (volume velocity $-2.0 \mathrm{~h}^{-1}$, reaction time $-1.0 \mathrm{~h}$ ): 1 - methanol conversion, 2 yield of propylene, 3 - yield of ethylene. 
Table 2. Acidic properties of catalysts [19], $T_{I}$ and $T_{I I}-$ maximum temperature peaks for desorption of ammonia; $C_{I}$ and $\mathrm{C}_{\mathrm{II}}-$ concentrations of acidic sites of I and II forms.

\begin{tabular}{|c|c|c|c|c|c|}
\hline \multirow{2}{*}{ Samples } & \multicolumn{2}{|c|}{$T_{\max },{ }^{0} \mathrm{C}$} & \multicolumn{3}{c|}{ Concentration of acidic sites, $\mu$ mol/g } \\
\cline { 2 - 6 } & $T_{\mathrm{I}}$ & $T_{\mathrm{II}}$ & $C_{\mathrm{I}}$ & $C_{\mathrm{II}}$ & $C_{\mathrm{I}} / C_{\mathrm{II}}$ \\
\hline HZSM-5 & 200 & 418 & 630 & 548 & 1.15 \\
\hline Zr-ZSM-5 & 196 & 370 & 402 & 311 & 1.24 \\
\hline La-ZSM-5 & 192 & 358 & 397 & 298 & 1.33 \\
\hline Zn-ZSM-5 & 196 & 360 & 448 & 312 & 1.43 \\
\hline Zn-La/ZSM-5 & 192 & 318 & 324 & 212 & 1.53 \\
\hline La-ZrZSM-5 & 190 & 309 & 312 & 172 & 1.81 \\
\hline Zn-ZrZSM-5 & 191 & 301 & 296 & 188 & 1.6 \\
\hline
\end{tabular}

Table 2 shows the data on the acidic properties of catalysts obtained by ammonia TPD. The introduction of various elements into the composition of a zeolite catalyst significantly affects the total number of acid sites. Only in the case of a $\mathrm{Zr}$-containing catalyst does the total acidity increase. The initial ZSM-5 zeolite in combination with aluminum oxide has the largest number of strong acid sites. Reducing the proportion of strong acid sites is observed only in the modification of $\mathrm{La}$ and $\mathrm{Zr}$. When comparing the acidic and catalytic properties of zeolite catalysts, some assumptions are made: a decrease in the total number of acid sites leads to an increase in the selectivity for lower olefins, and the ratio of average to strong acid sites plays a great role. Thus, the Zr-ZSM-5 catalyst, which has the largest number of acid sites while reducing the ratio of strong to medium acid sites, shows the highest selectivity for lower olefins among the mono-modified zeolitecontaining catalysts. The catalyst La-Zr/ZSM-5, which has the lowest proportion of strong to medium acidic centers, showed the best selectivity for ethylene and propylene.

Acidity is an important property of a catalyst that affects not only the stability of its operation, but also its selectivity. Two forms of ammonia desorption peaks observed for HZSM5. Desorption of ammonia at the temperature $T_{\mathrm{I}}$ $-198^{\circ} \mathrm{C}$ relates to weak acidic sites, and $T_{\mathrm{II}}-$ $418^{0} \mathrm{C}$ relates to strong ones. HZSM-5 zeolite has the greatest number of strong acid sites. Concentration of strong acid sites was 548 $\mu \mathrm{mol} / \mathrm{g}$. As a result of chemical modification of HZSM-5 with zinc, zirconium and lanthanum, there was a significant decrease in the concen tration of strong acid sites $(212-311 \mu \mathrm{mol} / \mathrm{g})$. The greatest decrease in stronger acid sites is observed upon double modification of the zeolite with $\mathrm{La}$ and $\mathrm{Zr}$ compounds. A fore mentioned studies of the acid and catalytic properties of modified zeolites established the role of weak and strong acid centers in the formation of ethylene and propylene. The selectivity of zeolite catalysts for ethylene and propylene is determined by the ratio of the proportion of weak and strong acid sites.

Thus, the activity and selectivity of zeolite catalysts with respect to ethylene and propylene determine are by the nature of the modifying metal and the ratio of the fractions of weak and strong acid sites.

\section{Reference}

1. Menshikov V.A., Sinev M.Iu. Proizvodstvo etilena iz prirodnogo gaza metodom okislitelnoi kondensatcii metana. Kataliz v promyshlennosti. 2005. № 1. S. 25-35.

2. Hadzhiev S.N., Kolesnichenko N.V., Ezhova N.N., Poluchenie nizshikh olefinov iz prirodnogo gaza cherez metanol i ego proizvodnye. Neftehimiia. 2008. T. 48. № 5. C. 323-333.

3. Majhi S., Mohanty P., Dalai A.K. Statistical Optimization of process variables for methane conversion over $\mathrm{Zn}-\mathrm{Mo} / \mathrm{H}-\mathrm{ZSM}-5$ catalysts in the presence of methanol. Energy Technology. 2013. V. 1. P. 157-165.

4. Zhao G.L., Teng J.W., Xie Z.K. Effect of phosphorus on HZSM-5 catalyst for $\mathrm{C}_{4}$-olefin cracking reactions to produce propylene. J. Catalysis. 2007. V. 248. P. 29.

5. Cai G., Liu Z., Shi R. Light alkenes from syngas via dimethyl ether. Applied Catalysis. A. General. 1995. V. 125. P. 29-38.

6. Liang J, Li H.Y, Zhao S.Q. etc. Characteristics and performances of SAPO-34 catalyst for methanol-to-olefin conversion. Applied Catalysis. 1990. V. 64. P. 31-40. 
7. Stöcker M. Methanol-to-hydrocarbons: catalytic materials and their behavior. Microporous and Mesoporous Materials. 1999. V. 29. No 1-2. P. 3-48.

8. Dubois D., Obrzut L., Liu J. Conversion of methanol to olefins over cobalt-, manganese- and nickelincorporated SAPO-34 molecular sieves. Fuel Processing Technology. 2003. V. 83. No 1-3. P. 203-218.

9. Mei C., Wen P., Liu Z., etc. Selective production of propylene from methanol: Mesoporosity development in high silica HZSM-5. J. of Catalysis. 2008. V. 258. No 1. P. 243-249.

10. Rostamizadeh M., Taeb A. Highly selective MeZSM-5 catalyst for methanol to propylene (MTP). J. Ind. Eng. Chem. 2015. V. 27. P. 297-306.

11. Sano T., Production of light olefins from methanol and ethanol using ZSM-5 type zeolite catalysts. J. Japan Petrol. Inst. 2017. V. 60. P. 263-276.

12. Strizhak P., Zhokh A., Trypolskyi A. Methanol conversion to olefins on $\mathrm{H}-\mathrm{ZSM}-5 / \mathrm{Al}_{2} \mathrm{O}_{3}$ catalysts: kinetic modeling. Reaction Kinetics, Mechanisms and Catalysis. 2018. V. 123. P. 247-268.

13. Zhao X.B., Wang L.Y., Li J.Z. Investigation of methanol conversion over high-Si beta zeolites and the reaction mechanism of their high propene selectivity. Catalysis Sci. Technol. 2017. V. 7. P. 5882-5892.
14. Zhokh A.A., Strizhak P.E. Pore size effect on the methanol anomalous diffusion in the mesoporous catalyst pellets for methanol-to-olefin reaction. Int. J. Heat Mass Transfer. 2017. V. 112. P. 1072-1080.

15. Shuxun T., Shengfu J., Qi S. Preparation of phosphorus modified HZSM-5 zeolite catalysts and their catalytic performances of methanol to olefins. Adv. Mater. Res. 2014. V. 875-877. P. 295-299.

16. Jin Y., Asaoka S., Zhang S. Reexamination on transition-metal substituted MFI zeolites for catalytic conversion of methanol into light olefins. Fuel Process. Technol. 2013. V. 115. P. 34-41.

17. Zhang Y.K., Qu Y.X., Wang D.L. Cadmium modified HZSM-5: a highly efficient catalyst for selective transformation of methanol to aromatics. Ind. Eng. Chem. Res. 2017. V. 56. P. 12508-12519.

18. Inui T, Phatanasri S, Matsuda H. Highly selective synthesis of ethene from methanol on the novel nickel-containing silicoaluminophosphate catalyst. J. Chem. Soc. Chem. Com. 1990. P. 205-206.

19. Qanbarova E.A., Babayeva T.A., Akhmedova N.F., Mamedov S.E. The transformation of natural gas and methanol on bimetallic zeolite catalysts. J. Environ. Sci. Comput. Sci. and Eng. Technol. 2019. V. 8. No 2. P. 160-166.

\title{
ZSM-5 SEOLIT OSASLI BIMMETALLIK KATALIZZATORLAR ISSTIRAKINDA METANOLUN KARBOHIDROGENLӘRӘ ÇEVRILMOSI
}

\begin{abstract}
T.ə.Babayeva
Keçid metalları - Zn, Zr və La ilə modifikasiya edilmiş ZSM-5 seolitləri üzərində metanolun karbohidrogenlərə çevrilməsi prosesi araşdırılmışdır. Selektiv olaraq $\mathrm{C}_{2}-\mathrm{C}_{3}$ olefinlərinin alınması üçün reaksiya parametrlərinin temperatur, kontakt müddəti və katalizatorun Brensted turşuluğunun asılılığ xarakterizə edilmiş və şərh olunmuşdur. ZSM-5-in ikili modifikasiyasınin əsas məhsulların seçiciliyini artırdığı aşkar edilmişdir. La-Zr/HZSM-5 katalizatorunun bəzi unikal xüsusiyyətlərinin güclü və zəif turşu mərkəzlərinin nisbəti və paylanmasından qaynaqlanması göstərilmişdir.

Açar sözlor: seolit, ZSM-5, HZSM, Zn, Zr, La, MTO, MTP, metanol, etilen, propilen.

\section{ПРЕВРАЩЕНИЕ МЕТАНОЛА В УГЛЕВОДОРОДЫ НА БИМЕТАЛЛИЧЕСКИХ КАТАЛИЗАТОРАХ НА ОСНОВЕ ЦЕОЛИТА ТИПА ZSM-5}

\section{Т.А.Бабаева}

Описана конверсия метанола в углеводороды на цеолите ZSM-5, модифицированном переходными металлами $\mathrm{Zn}, \mathrm{Zr}$ и La. Характеризуется и интерпретируется взаимозависимость температуры реакции, времени контакта и кислотности катализатора при контроле селективности олефинов $\mathrm{C}_{2}-\mathrm{C}_{3}$. Установлено, что бинарная модификация ZSM-5 повышает селективность целевых продуктов. Некоторые из уникальных свойств катализатора $\mathrm{La}-\mathrm{Zr} / \mathrm{HZSM}-5$, по-видимому, обусловлены сочетанием сильнокислотных и слабокислотных центров.
\end{abstract}

Ключевые слова: иеолит, ZSM-5, HZSM, Zn, Zr, La, MTO, МТП, метанол, этилен и пропилен. 